ISSN 0258-7122

Bangladesh J. Agril. Res. 39(2): 263-271, June 2014

\title{
GENETIC DIVERSITY OF FRUIT BORER, HELICOVERPA ARMIGERA (LEPIDOPTERA: NOCTUIDAE) BASED ON RANDOM AMPLIFIED POLYMORPHIC DNA- POLYMERASE CHAIN REACTION
}

\author{
A. K. M. Z. RAHMAN ${ }^{1}$, M. A. HAQUE ${ }^{2}$, S. N. ALAM ${ }^{3}$ \\ P. YASODHA ${ }^{4}$ AND V. BALASUBRAMANI ${ }^{5}$
}

\begin{abstract}
The genetic variability of Helicoverpa armigera (Hübner) at different agroecological zones of Bangladesh in comparison with Indian population was conducted in India during September 2008 to February 2009. A total of $12 \mathrm{H}$. armigera populations of which 10 populations collected from different agroecological zones of Bangladesh and two populations from India were tested for their genetic variability. Eight out of the ten primers produced scorable PCR products by amplifying the template DNA with taq polymerase and were subjected for analysis. Those eight primers got amplified to a total of 138 markers which produced polymorphic markers. The similarity coefficient based on 138 RAPD markers ranged from 0.000 to 0.777 of the pair-wise combination among twelve samples of $H$. armigera. An UPGMA dendrogram based on Jaccard's similarity coefficient was constructed for the 12 samples of $H$. armigera. The dendrogram showed that $H$. armigera population from Bangladesh had 25 to 45 percent similarity, and in its Indian population the similarity remained within this range.
\end{abstract}

Keywords: Helicoverpa armigera, genetic diversity, RAPD-PCR, primers.

\section{Introduction}

Fruit borer, Helicoverpa armigera (Hübner) is widely distributed in Asia, Africa, Australia, and the Mediterranean Europe, while Heliothis virescens and Helicoverpa zea are widely distributed in the Americas (Reed \& Power, 1982). Being polyphagous, this pest feeds on more than 500 plant species, including economically important crops, such as cotton, maize, sorghum, chickpea, pigeon pea, sunflower, vegetables, and fruits. They cause an estimated loss of over US\$ 5 billion annually despite application of pesticides costing over US\$ 1 billion every year. (Sharma, 2005). In Bangladesh, Helicoverpa armigera is becoming an alarming pest in different vegetable crops. It was reported that infestation range of $H$. armigera on tomato was up to 46.85 percent at Jessore (Alam et al.,

\footnotetext{
${ }^{1 \& 3}$ Senior Scientific Officer and Chief Scientific Officer, respectively, Entomology Division, Bangladesh Agricultural Research Institute (BARI), Gazipur-1701, ${ }^{2}$ Professor, Department of Entomology, Bangladesh Agricultural University (BAU), Mymensingh, Bangladesh, ${ }^{4}$ Assistant Professor (Agril. Entomology), Department of Agril. Processing \& Basic Sciences, Agricultural Engineering College and Research Institute, Kumulur, Trichi, Tamil Nadu, India, ${ }^{5}$ Professor (Agril, Entomolology), Dept. of Plant Biotechnology, CPMB, Tamil Nadu Agricultural University, Tamil Nadu, India
} 
2007). In recent times, crop production has been severely affected in controlling the pests as they have developed high level of resistance to the commonly used insecticides worldwide. Fruit borer has developed a high level of resistance to many of the commonly used pesticides (Kranthi et al., 2002). Insecticide resistance in $H$. armigera leads to heterogeneity in population.

In general, Helicoverpa species have been described as preferentially feeding on buds, flowers, and fruits. The preference of fruiting structures and the tendency to move from one fruit to another, often without consuming it completely, is the main reason why extensive damage often results to crops even when the number of large larvae is relatively low (Zalucki et al., 1986). Damaged flowers and young fruits may fall off. Damaged fruits have roughly spherical holes made by fully mature larvae through which they escape the host plant for pupation in soil. Older fruits rot or become deformed. A single caterpillar may eat and destroy $2-8$ fruits. $H$. armigera is abundant throughout Bangladesh. Its damage severity varies from place to place. There might exist some genetically variation in $H$. armigera of different agro-ecological zones of Bangladesh.

The versatility of this species may be due to the presence of a strong genetic variability governing the behaviour of $H$. armigera (Zhou et al., 2000; Scott et al., 2003) making it a serious pest on several crops. In this regard, a better understanding of the genetic differences of polyphagous pest like $H$. armigera can be very useful to the structure and population dynamics, their behavior and response to various selection pressures. Therefore, an attempt was made to study the genetic variation of $H$. armigera using RAPD markers.

\section{Materials and method}

This study was conducted in the Department of Plant Molecular Biology and Biotechnology, Centre for Plant Molecular Biology, Tamil Nadu Agricultural University, Coimbatore, India during September 2008 to February 2009.

\section{Sampling of insect}

H. armigera larvae collected from different locations of Bangladesh and were reared at IPM laboratory, Entomology Division, BARI separately using their respective hosts. Indian $H$. armigera populations were also reared separately in their respective hosts. The emerged female from each locality was preserved immediately in vials containing 70 percent alcohol. The samples were maintained at $-20^{\circ} \mathrm{C}$ until DNA extraction. A total of 10 samples of $\mathrm{H}$. armigera were collected from 10 different localities of Bangladesh on different hosts like tomato, chickpea, chili, and mungbean during March to May of 2008. For comparison, two populations of $H$. armigera were collected from two locations of Coimbatore, Tamil Nadu, India during October 2008. Hence, a total of 12 
samples were collected from 12 different localities depicting a garden-land ecosystem with field and horticultural crops that are being grown round the year (Table 1).

Table 1. Sample collected from different locations for assessing diversity in $\boldsymbol{H}$. armigera populations from different host plants.

\begin{tabular}{l|l|l|l|l}
\hline Plant source & Date of sampling & Location & Geographic coordinate & Population code \\
\hline Tomato & $27 / 4 / 2007$ & Gazipur & $22^{\circ} 78^{\prime} \mathrm{N} 90^{\circ} 20^{\prime} \mathrm{E}$ & TOGAZ \\
Tomato & $30 / 4 / 2007$ & Mymensingh & $24^{\circ} 45^{\prime} \mathrm{N} 90^{\circ} 24^{\prime} \mathrm{E}$ & TOMYM \\
Tomato & $01 / 5 / 2007$ & Comilla & $23^{\circ} 28^{\prime} \mathrm{N} 91^{\circ} 10^{\prime} \mathrm{E}$ & TOCOM \\
Tomato & $25 / 4 / 2007$ & Norsingdhi & $23^{\circ} 92^{\prime} \mathrm{N} 90^{\circ} 71^{\prime} \mathrm{E}$ & TONOR \\
Mungbean & $10 / 5 / 2007$ & Pabna & $24^{\circ} 01^{\prime} \mathrm{N} 89^{\circ} 18^{\prime} \mathrm{E}$ & MBPAB \\
Chili & $1 / 5 / 2007$ & Rajbari & $23^{\circ} 75^{\prime} \mathrm{N} 89^{\circ} 65^{\prime} \mathrm{S}$ & $\mathrm{CHIRAJ}$ \\
Chili & $3 / 5 / 2007$ & Manikgonj & $23^{\circ} 51^{\prime} \mathrm{N}$ & $\mathrm{CHIMAN}$ \\
& & & $90^{\circ} 0^{\prime} \mathrm{E}$ & \\
Mungbean & $12 / 5 / 2007$ & Ishurdi & $24^{\circ} 8^{\prime} \mathrm{N}$ & MBISD \\
& & & $89^{\circ} 5^{\prime} \mathrm{E}$ & \\
Mungbean & $02 / 5 / 2007$ & Magura & $24^{\circ} 46^{\prime} \mathrm{N} 89^{\circ} 15^{\prime} \mathrm{E}$ & $\mathrm{MBMAG}$ \\
Mungbean & $15 / 5 / 2007$ & Jessore & $23^{\circ} 10^{\prime} \mathrm{N} 89^{\circ} 10^{\prime} \mathrm{E}$ & $\mathrm{MBJES}$ \\
Chick pea & $01 / 10 / 2008$ & Coimbatore & $11^{\circ} 00 \mathrm{~N} 77^{\circ} 00 \mathrm{E}$ & $\mathrm{CPCO}$ \\
Chick pea & $03 / 10 / 2008$ & Trichy & $10^{\circ} 48^{\prime} 8 \mathrm{~N} 78^{\circ} 1^{\prime} 7^{\prime} \mathrm{E}$ & $\mathrm{CPTRY}$ \\
\hline
\end{tabular}

\section{DNA extraction}

Total nucleic acids were extracted from individual female of $H$. armigera using C-TAB (Hexadecyl trimethyl ammonium bromide) method (Doyle and Doyle, 1987) with some modifications. Modifications were made as follows: 1 . Second wash of crude DNA with Chloroform and iso amyl alcohol is prevented. 2. Washing of crude DNA with sodium acetate 3. Washing with $70 \%$ ethanol for several times is limited based on the final crude DNA pellet obtained. Single washing of crude DNA with ethanol was maximum followed. Quantity of the isolated DNA was measured in NanoDrop ${ }^{\circledR}$ ND-1000 spectrophotometer and the quality were checked in $0.8 \%$ Agarose gel electrophoresis before using it as the template for polymerase chain reactions (PCR). The reagents were purchased from Bangalore Genei Ltd., Bangalore, India.

\section{RAPD assays}

Amplification reactions were performed in a $20 \mu \mathrm{L}$ reaction mix, containing a final concentration of $2.5 \mathrm{mM}$ dNTPs, $25 \mathrm{mM} \mathrm{MgCl}$, dimethyl sulfoxide, Taq polymerase $3 \mathrm{U} / \mu \mathrm{L}, 10 \mathrm{x}$ Taq buffer, sterile water, primer $100 \mathrm{nmol}$ and DNA 20- 
$25 \mathrm{ng} / \mathrm{uL}$. The RAPD analysis was performed with seventeen decamers supplied by Operon Technologies Inc., California, USA. Amplification was performed in thermocycler (BioRad, USA) programmed as one cycle of initial denaturation at $95^{\circ} \mathrm{C}$ for $2 \mathrm{~min}$; one cycle of denaturation at $95^{\circ} \mathrm{C}$ for $1 \mathrm{~min} ; 30$ cycles each of $95^{\circ} \mathrm{C}$ for $1 \mathrm{~min}$., annealing at $40^{\circ} \mathrm{C}$ for $1 \mathrm{~min}$., extension at $72^{\circ} \mathrm{C}$ for $1 \mathrm{~min}$. and final extension at $72^{\circ} \mathrm{C}$ for $7 \mathrm{~min}$. The PCR products were separated in $1.5 \%$ agarose gel electrophoresis.

\section{Analysis of PCR amplification profiles}

Data obtained by scoring the RAPD profiles of the eight primers individually were subjected to cluster analyses. PCR amplification products of the 12 samples were scored as presence (1) or absence (0) of bands. The data matrix was used to calculate Jaccard's similarity coefficient (Sneath and Sokal, 1973), which does not consider the joint absence of a marker as an indication of similarity. The similarity values were used for cluster analyses. Sequencial agglomerative hierarchial non-overlapping (SAHN) clustering was done using Unweighted PairGroup method with arithmetic averages (UPGMA). This analysis was performed using NTSYS-PC software, version 2.0 (Rohlf, 1998).

\section{Results and Discussion}

Eight out of the ten primers screened produced scorable PCR products by amplifying the template DNA with taq polymerase and were subjected for analysis. These eight primers (Table 2) got amplified to a total of 138 markers and all the primers produced amplified polymorphic markers. The total number of clear bands obtained from each primer ranged from 34 (OPA 02) to 6 (OPE 15) with an average of 17.25 bands per primer. The size of the amplicons ranged from $100 \mathrm{bp}$ to more than $1000 \mathrm{bp}$, while clearly resolved bands were seen only below $800 \mathrm{bp}$ in case of OPA 13 primer. RAPD amplification pattern is shown in Fig. 1 and 2 for illustration. Genetic relationships between populations are shown in Table 3.

The similarity coefficient based on 138 RAPD markers ranged from 0.000 to 0.777. Of the pair-wise combination among 12 samples of $H$. armigera, CPCO (Chick pea from Coimbatore) location got the minimum similarity index $(0.000)$ and the maximum index (0.777) was seen in TOMYM (Tomato from Mymensingh region). An UPGMA dendrogram based on Jaccard's similarity coefficient was constructed for the twelve samples of $H$. armigera. Two major clusters viz., A and B are evident from the dendrogram (Fig. 2). PCR screening demarcates the $H$. armigera population based on the locality. The major cluster $\mathrm{A}$ is again divided into minor groups viz., $\mathrm{A}_{1}, \mathrm{~A}_{2}, \mathrm{~A}_{3}$ and $\mathrm{A} 4$. The minor cluster $\mathrm{A}_{1}$ is comprised population from TOGAZ (Tomato host plants from Gazipur), 
TOMYM (Tomato from Mymensingh region) and TONOR (Tomato from Norshindhi region), while $\mathrm{A}_{2}$ comprised TOCOM (Tomato from Comilla region), MBPAB (Mung bean from Pabna region), CHIRAJ (Chili from Rajbari region), CHIMAN (Chili from Manikgonj region) and MBISD (Mung bean from Ishurdi region), while $\mathrm{A}_{3}$ comprised MBMAG (Mung bean from Magura region), and $\mathrm{A}_{4}$ comprised MBJES (Mung bean from Jessore region). The major cluster B is further divided into $B_{1}$ and $B_{2}$. The minor cluster $B_{1}$ represented the population of $H$. armigera collected from Coimbatore and $\mathrm{B}_{2}$ represented chickpea from Trichy. The dendrogram deduced that $H$. armigera population from Bangladesh had 25 to 45 percent similarity, while 30 percent similarity was observed for population from India.

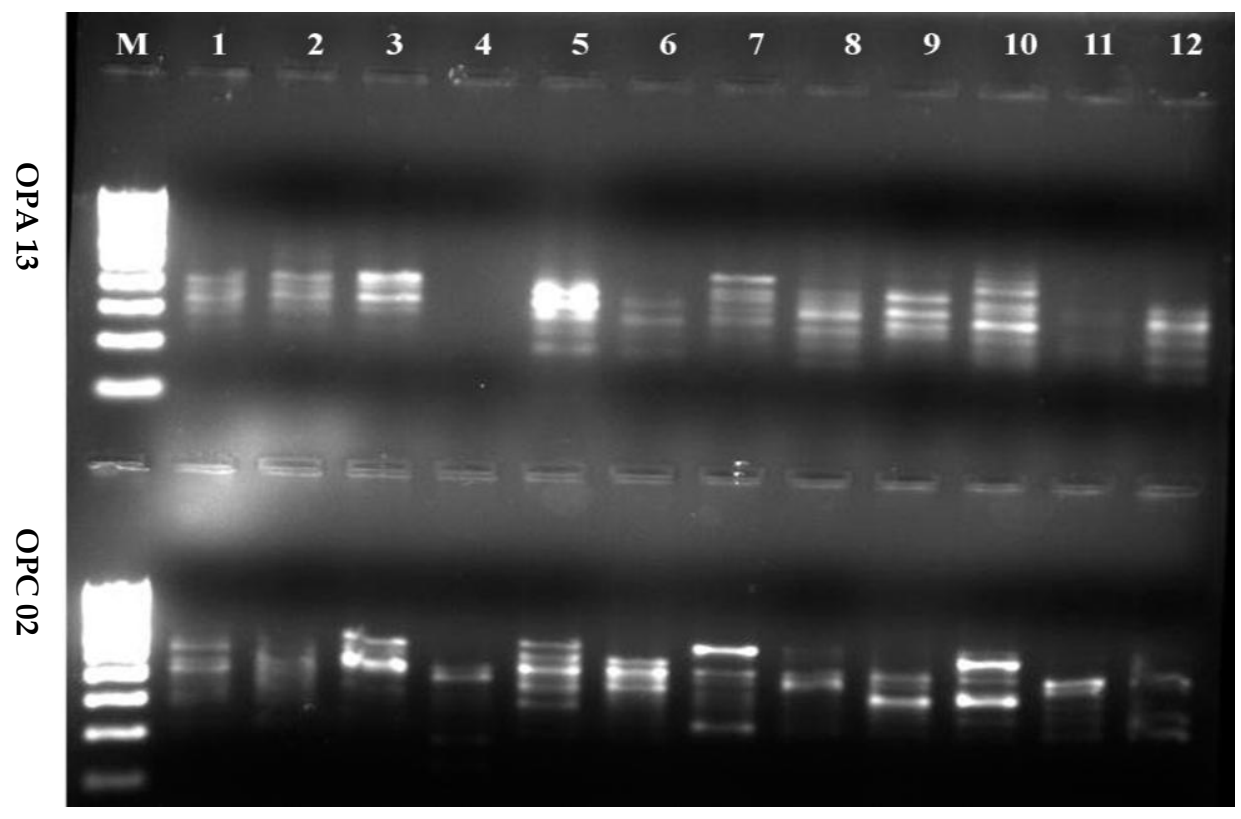

Fig. 1. Agarose gel electrophoretic profile from twelve populations of $\boldsymbol{H}$. armigera: 1. Gazipur tomato; 2. Mymensingh tomato; 3. Comilla tomato; 4. Norshindi tomato; 5. Manikgonj Chili; 6. Rajbari Chili; 7. Ishurdi mungbean; 8. Pabna mungbean; 9. Magura mungbean; 10. Jessore mungbean; 11. Coimbatore chickpea; 12 . Trichy chickpea, $M=100$ bp ladder 


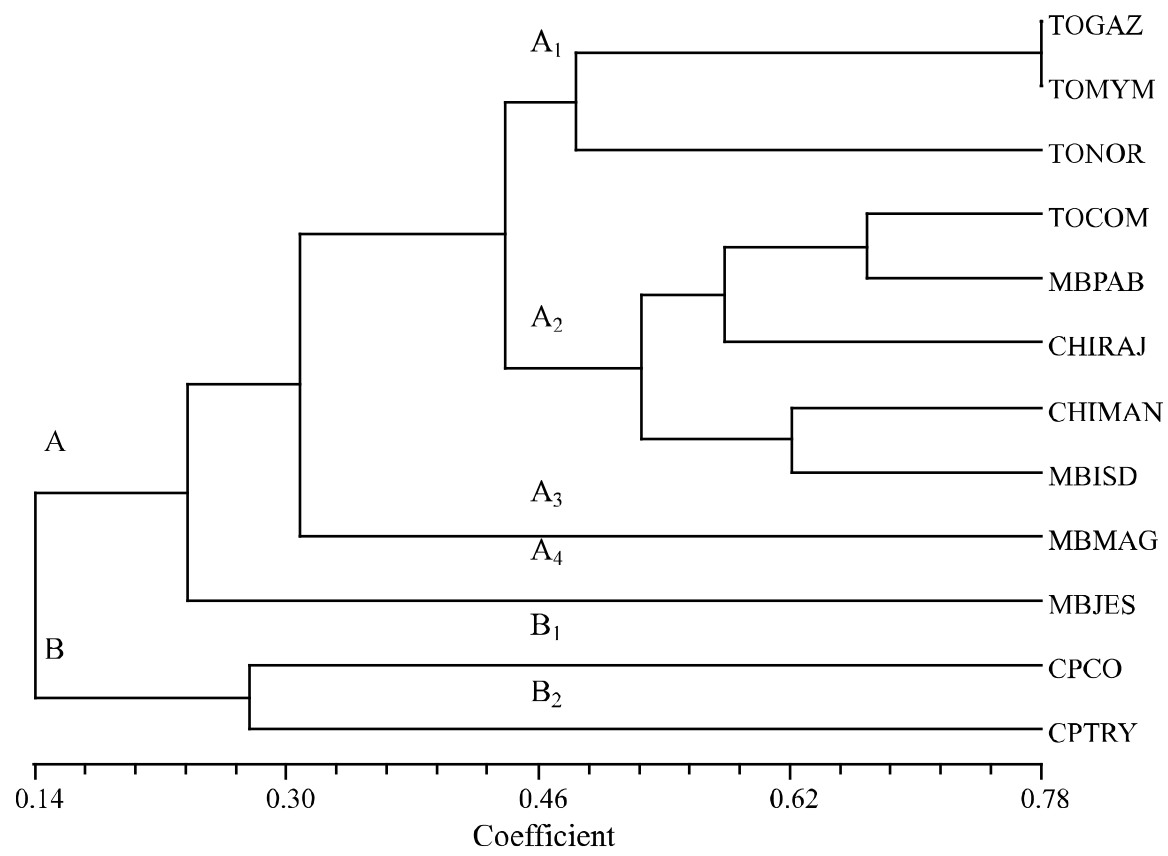

Fig. 2. Dendrogram based on Jaccard's similarity coefficient showing relationship among $H$. armigera populations from different host plants and regions of Bangladesh and India using RAPD markers

TOGAZ =Tomato from Gazipur region, TOMYM= Tomato from Mymensingh region, TONOR $=$ Tomato from Norsindi region, TOCOM= Tomato from Comilla region, $\mathrm{MBPAB}=$ Mung bean from Pabna region, CHIRAJ = Chili from Rajbari region, $\mathrm{CHIMAN}=$ Chili from Manikgonj region, MBISD= Mung bean from Ishurdi region, $\mathrm{MBMAG}=$ Mung bean from Magura region, MBJES= Mung bean from Jessore region, $\mathrm{CPCO}=$ Chick pea from Coimbatote, Tamil Nadu, CPTRY $=$ Chick pea from Trichi, Coimbatore, Tamil Nadu

This finding is supported by Gujar et al. (2007) who showed that six out of eight pairs of molecular markers were able to amplify the cadherin gene in eighteen insect populations of $H$. armigera collected from different locations in India and produces a total of 218 amplicons. The maximum similarity (96\%) was found for three pairs of insect populations from Rajkot and Sirsa, Akola and Bhatinda, and Faridkot and Karnal; while the minimum similarity (82\%) was for the pair of insect populations from Nanded and Hyderabad. The study showed 4 $18 \%$ genetic diversity in cadherin-specific gene of $H$. armigera populations which differed at least 100 -fold in their susceptibility to Cry1Ac. Chen et al. (2000) reported that genetic variations of $H$. armigera (Hubner) over different major cotton growing regions were analyzed by DNA polymorphism amplified with four simple repetitive sequence primers. The results showed that the laboratory population had lower genetic variation than natural populations. The 
genetic variation between natural populations was not significant and genetic variation existed in the same location from different years, indicating frequent migration among natural cotton bollworm populations.

Table 2. Total number of markers and percentage of polymorphism developed among $H$. armigera population from different host plants and different regions by the RAPD primers.

\begin{tabular}{cccccc}
\hline $\begin{array}{c}\text { Primer } \\
\text { name }\end{array}$ & $\begin{array}{c}\text { No.of markers } \\
\text { generated }\end{array}$ & $\begin{array}{c}\text { Polymorphic } \\
\text { markers }\end{array}$ & $\begin{array}{c}\text { Monomorphic } \\
\text { markers }\end{array}$ & $\begin{array}{c}\text { Percent } \\
\text { Polymorphism }\end{array}$ \\
\hline OPA 13 & 25 & 25 & - & 100.00 \\
OPC 02 & 22 & 22 & - & 100.00 \\
OPA 02 & 34 & 34 & - & 100.00 \\
OPA 07 & 18 & 18 & - & 100.00 \\
OPC 08 & 17 & 17 & - & 100.00 \\
OPE 15 & 6 & 6 & - & 100.00 \\
OPA 01 & 9 & 9 & - & 100.00 \\
OPI 12 & 7 & 7 & - & 100.00 \\
\hline
\end{tabular}

Table 3. Genetic similarity matrix among $\boldsymbol{H}$. armigera populations.

\begin{tabular}{l|c|c|c|c|c|c|c|c|c|c|c|c}
\hline Case & $\mathbf{1}$ & $\mathbf{2}$ & $\mathbf{3}$ & $\mathbf{4}$ & $\mathbf{5}$ & $\mathbf{6}$ & $\mathbf{7}$ & $\mathbf{8}$ & $\mathbf{9}$ & $\mathbf{1 0}$ & $\mathbf{1 1}$ & $\mathbf{1 2}$ \\
\hline $\mathbf{1}$ & 1.000 & & & & & & & & & & & \\
$\mathbf{2}$ & 0.777 & 1.000 & & & & & & & & & & \\
$\mathbf{3}$ & 0.466 & 0.466 & 1.000 & & & & & & & & & \\
$\mathbf{4}$ & 0.416 & 0.545 & 0.437 & 1.000 & & & & & & & & \\
$\mathbf{5}$ & 0.400 & 0.400 & 0.545 & 0.450 & 1.000 & & & & & & & \\
$\mathbf{6}$ & 0.277 & 0.277 & 0.526 & 0.333 & 0.521 & 1.000 & & & & & & \\
$\mathbf{7}$ & 0.571 & 0.571 & 0.647 & 0.533 & 0.619 & 0.380 & 1.000 & & & & & \\
$\mathbf{8}$ & 0.357 & 0.461 & 0.666 & 0.538 & 0.476 & 0.625 & 0.562 & 1.000 & & & & \\
$\mathbf{9}$ & 0.176 & 0.250 & 0.238 & 0.166 & 0.280 & 0.227 & 0.238 & 0.277 & 1.000 & & & \\
$\mathbf{1 0}$ & 0.105 & 0.166 & 0.350 & 0.222 & 0.434 & 0.400 & 0.350 & 0.411 & 0.250 & 1.000 & & \\
$\mathbf{1 1}$ & 0.083 & 0.083 & 0.187 & 0.076 & 0.190 & 0.176 & 0.117 & 0.142 & 0.000 & 0.200 & 1.000 & \\
$\mathbf{1 2}$ & 0.062 & 0.062 & 0.150 & 0.125 & 0.208 & 0.200 & 0.277 & 0.176 & 0.050 & 0.157 & 0.272 & 1.000 \\
\hline
\end{tabular}

1-TOGAZ =Tomato from Gazipur region, 2-TOMYM= Tomato from Mymensingh region, 3- TOCOM= Tomato from Comilla region 4-TONOR= Tomato from Norsindi Region, 5- CHIMAN= Chili from Manikgonj region 6-CHIRAJ = Chili from Rajbari region 7-MBISD= Mung bean from Ishurdi region, $8-\mathrm{MBPAB}=$ Mung bean from Pabna region, , 9-MBJES= Mung bean from Jessore region 10-MBMAG= Mung bean from Magura region, , 11-CPCO $=$ Chick pea from Coimbatore, Tamil Nadu, 12-CPTRY= Chick pea from Trichi, Coimbatore, Tamil Nadu 
Subramanian and Mohankumar (2006) showed in their preliminary study using 10 microsatellite simple sequence repeat (SSR) markers the genetic variability of $H$. armigera populations from six different host plants with nine SSR primers indicating high variability across the different host associated populations with polymorphism ranging from 75 to 100 percent and high similarity among populations collected from vegetable crops and more variable while the population collected from the cotton crop. This phenomenon indicates a strong genetic variability among $H$. armigera populations collected from different host plants. Shravankumar and Jagdaishwar (2004) found differences in susceptibility to different insecticides among $H$. armigera populations collected from three hosts, chickpea, tomato, and grapes. The authors suggested that this difference might be due to the variation in plant factors. The results of the present study also suggest that genetic variation among populations collected from different host plants might be due to host characteristics.

Moya et al. (2001) and Maruthi et al. (2001) studied genetic diversity on whitefly, Bemisia tabaci genomic DNAs using RAPD-PCR. Molecular characterization of insects has been frequently conducted on the basis of existence of polymorphic DNA fragments amplified by PCR (Caterino et al., 2000). Williams et al. (1994) have reported geographical distribution of Argentine stem weevils, Listronotus bonariensis (Kuschel), by RAPD-PCR using genomic DNAs. Within the last few years, techniques using the polymerase chain reaction (PCR) to amplify genomic regions have become widespread (Saiki et al., 1988). Williams et al. (1993) reported that RAPD PCR process reveals polymorphism in the genomes of a wide variety of insect species.

\section{References}

Alam S. N., A. K. M. Z. Rahman and N. K. Dutta. 2007. Annual Report. Division of Entomology, BARI, Gazipur-1701. 163P.

Caterino, M. S., S. Cho and F. A. H. Sperling. 2000. The current stage of insect molecular systematics: a thriving Tower of Babel. Annual Review of Entomology 45: 1-54.

Chen, X. F., S. J. Tan, R. Y Liu, Y. Wang and D. M. Li. 2000. Study on the genetic variation of the cotton bollworm Helicoverpa armigera (Hübner) populations in China. Insect Science 7: 243-249.

Doyle, J. J. and J. L. Doyle. 1987. A rapid DNA isolation procedure from small quantities of fresh leaf tissue. Phytochem. Bull. 19: 11-15.

Gujar, G. T., R. N. Khawale and V. Kalia. 2007. Genetic variability of Helicoverpa armigera (Hübner) attributable to cadherin gene-specific molecular markers. Current Science 92: 800-804.

Kranthi, K. R., D. R. Jadhav, S. Kranthi, R. R. Wanjari, S. S. Ali and D. A. Russel. 2002. Insecticide resistance in five major insect pests of cotton in India. Crop Protect. 21: 449-460. 
Maruthi, M. N., J. Colvin and S. Seal. 2001. Mating compatibility, life history traits and RAPD- PCR variation in Bemisia tabaci associated with the cassava mosaic disease pandemic in East Africa. Entomologia Experimentalis et Applicata 99: 13-23.

Moya, A., P. Guirao, D. Cifuentes, F, Beitas. and J. L.Cenis. 2001. Genetic diversity of Iberian populations of Bemisia tabaci (Hemiptera: Aleyrodidae) based on RAPDPCR. Molecular Ecology 10: 891-897.

Reed, W. and C. S. Pawar. 1982. Heliothis: a global problem. In: Reed W, Kumble V (Editors), Proceedings of the International Workshop on Heliothis Management. Pantanchera, India, ICRISAT. Pp. 9-14.

Rohlf, F. J. 1998. NTSYS-PC (Numerical Taxonomy and Multivariate Analysis System). Ver. 2. Department of ecology and Evolution, State University of New York. Exeter Publ. Ltd., Setauket, N. Y., USA.

Saiki, R. K., Gelfand, D. H., Stoffel, S., Scharf, S. J., Higuchi, R., Horn, G. T., Mullis, K. B., and Erlich, H. A. 1988. Primer-directed enzymatic amplification of DNA with a thermostable DNA polymerase. Science 239: 487-491.

Scott, K. D., Lange, C. L., Scott, L. J. and Graham, G. C. 2003. Isolation and characterization of microsatellite loci from Helicoverpa armigera. Hübner (Lepidoptera: Noctuidae). Molecular Ecology Notes 4: 204-205.

Sharma, H. C. 2005. Heliothis/Helcoverpa management emerging trends and strategies for future research, Oxford \& IBH publishing Co. Pvt. Ltd. 469P.

Sneath, P. H. A. and R. R. Sokal. 1973. Numerical Taxonomy. The Principles and Practice of Numerical Classification. Freeman, San Francisco. 573P.

Subramanian, S and S. Mohankumar, 2006. Genetic variability of the bollworm, Helicoverpa armigera, occurring on different host plants. Journal of Insect Science 6: $26-34$.

Shravankumar, R. and R. D. Jagdishwar. 2004. Insecticide resistance to Helicoverpa armigera (Hübner) on three host crops. Indian Journal of Plant Protection 32: 136-138.

Williams, C. L, S. L. Goldson, D. B. Baird and D. W. Bullock . 1994. Geographical origin of an introduced insect pest, Listronotous bonariensis (Kuschel) determined by RAPD analysis. Heredity 72: 412.

Williams, J. G. K., M. K. Hanafey, J. A. Rafalski and, S. V. Tingey. 1993. Genetic analysis using random amplified polymorphic DNA markers. In: R. Wu (ed.) Methods in enzymology. Academic Press, New York 218: 704-740.

Zalucki, M. P., G. Daglish, S. Firempong and P. Twine. 1986. The biology and ecology of Heliothis armigera (Hubner) and $H$. punctigera Wallengren (Lepidoptera: Noctuidae) in Australia: What do we know? Australian Journal of Zoology 34: 779-814.

Zhou, X., O. Factor, S. W. Applebaum and Coll, M. 2000. Population structure of pestiferous moth Helicoverpa armigera using RAPD analysis. Heredity 85: 251-256. 